\title{
Covid-19: A Silent Killer
}

\author{
Nikita Birhman $^{1 *}$, Mithilesh Kumar Singh ${ }^{2}$, Shipra Tomar ${ }^{3}$ and Shrutika Pundir ${ }^{4}$ \\ ${ }^{1}$ Medical Microbiology, School of Medical Sciences \& Research, \\ Sharda University, Greater Noida, Uttar Pradesh, India-201306 \\ ${ }^{2}$ Medical Biochemistry, Noida International Institute of Medical Sciences, \\ Greater Noida, Uttar Pradesh, India-203201 \\ *Corresponding author
}

\section{A B S T R A C T}

\begin{tabular}{|c|}
\hline Keywords \\
\hline $\begin{array}{l}\text { COVID-19, Corona } \\
\text { Virus, RNA virus, } \\
\text { Public health, } \\
\text { Pandemic }\end{array}$ \\
\hline Article Info \\
\hline $\begin{array}{l}\text { Accepted: } \\
23 \text { April } 2020 \\
\text { Available Online: } \\
10 \text { May } 2020\end{array}$ \\
\hline
\end{tabular}

\section{Introduction}

The symptoms such as pneumonia, fever, breathing difficulty, and lung infection are commonly shown by coronavirus belong to a family of viruses. The World Health Organization (WHO) on $11^{\text {th }}$ February 2020 announced this virus official name as COVID-19 which full form is Corona Virus Infectious Disease and 19 indicates that it originated in 2019. The COVID-19 outbreak takes place first in Wuhan city of China on 29 December 2019 as the cause of an outbreak of respiratory illness. ${ }^{(1)}$

Coronaviruses belong to the largest group of viruses the Nidovirales order, which includes Coronaviridae, Arteriviridae, Mesoniviridae, and Roniviridae families. The viruses belong to Nidovirales order are enveloped, nonsegmented positive-sense RNA viruses. Coronavirus is spherical with diameters of 
approximately $125 \mathrm{~nm}$. The prominent feature of Coronaviruses is the spike projections with a crown-like structure on that which is the defining feature and that too gives its name as Corona Virus. Within the envelope of the virion is the nucleocapsid which is uncommon among positive-sense RNA viruses, but far more common for negativesense RNA viruses. ${ }^{(2)}$

COVID -19 is a public health emergency of international concern but to date, no known specific, effective, proven, pharmacological treatment available. Some studies suggested that chloroquine, an immune-modulating drug traditionally used to treat malaria, is effective in reducing viral replication in other infections, including the Server Acute Respiratory Syndrome Corona Virus (SARS$\mathrm{COV}$ ) and Middle East Respiratory Syndrome Corona Virus (MERS-CoV). ${ }^{(3)}$

\section{Epidemiology}

In Wuhan city, many cases of pneumonia were reported in December 2019. ${ }^{(4)}$ The first case of the COVID-19 epidemic was discovered on 12 Dec 2019 ${ }^{(5)}$. The WHO Director-General Dr. Tedros Adhanom Ghebreyesus announced on February 11, 2020, that the disease is caused by new CoV. Globally, $5^{\text {th }}$ May 2020 there have been $3,489,053$ confirmed cases of COVID-19, including 241,559 deaths, reported to WHO whereas according to the Ministry of Health and Family Welfare of India there have been 31967 active cases, 13160 cured /discharged, 1583 deaths and 1 migrated.

\section{Pathogenesis}

The genome structure of Coronaviruses is best known among all RNA viruses. Out of total RNA, two-thirds of RNA they have encodes viral polymerase (RdRp), RNA synthesis materials, and two large nonstructural polyproteins which not involved in host response modulation (ORF1a-ORF1b) and the other one-third of the genome encodes four structural proteins spike, envelope, membrane, nucleocapsid, and the other helper proteins. ${ }^{(6)}$ In the virus infection, the first step is with Spike Protein which interacts with sensitive human cells. After entering the cell genome it encoding occurs which encodes useful accessory proteins and that protein facilitates the expression of genes and that leads to adaptation of CoVs to their human host. ${ }^{(7)}$ The changes in the genomes resulting from recombination, gene exchange, gene insertion, or deletion are frequent among CoVs, and this will take place in future outbreaks. $^{(8)}$

\section{Symptoms of Covid -19}

According to the World Health Organization (WHO) and the Centers for Disease Control and Prevention (CDC), the common symptoms are:

Dry cough
Fever
Sore throat
Shortness of breath
Headache
Body aches
Exhaustion

\section{Diagnostics}

Among the many diagnostic platforms available Real-Time Polymerase Chain Reaction (RT-PCR) remains the primary means for diagnosing the health emergence of 2019-nCoV. ${ }^{(9)}$ The period and type of specimen collected play an important role in the diagnosis of 2019-nCoV. It was found that the respiratory specimens were positive for the virus while serum was negative in the early period and the serum as a specimen needs to be studied further. It has also 
suggested that in the early days of illness, patients have high levels of the virus despite the mild symptoms.

The most commonly used diagnosing method was RT-PCR in MERS-CoV. RT-LAMP has similar sensitivity as real-time RT-PCR. It is highly specific and used to detect MERS$\mathrm{CoV}$. It is rapid, simple, and convenient comparable to the usual diagnostic tests.

\section{Potential vaccines}

A wide range of technology (such as messenger RNA, DNA-based, nanoparticle, synthetic, and modified virus-like particle) about 15 potential vaccine candidates in the pipeline globally with the emergence of 2019nCoV, was applied. However, the kit developed by the Beijing Genomics Institute (BGI) has passed an emergency approval procedure of the National Medical Products Administration and used in clinical and surveillance centers of China. ${ }^{(19)}$ All 15 potential vaccine candidates were reported to be safe, well-tolerated, and able to trigger the relevant and appropriate immune responses for SARS and MERS. ${ }^{(20)}$

\section{Discussion}

Despite the efforts of the entire world to grasp COVID-19, many issues remain unclear. ${ }^{(34)}$ The Director-General of WHO declared the outbreak of COVID-19 as a Public Health Emergency of International Concern on 30 January 2020. The disease spectrum ranges from mild to life-threatening. ${ }^{(35)}$

The clinical manifestation of COVID-19 ranges from asymptomatic carrier state to severe pneumonia as early reports mostly showed the findings of SARS-CoV-2 pneumonia within which the ratio of male patients was much larger than that of female patients. ${ }^{(35)}$ Besides, as most of the studies are being conducted everywhere the globe it's important to clarify the epidemiologic characteristics of COVID-19. Respiratory droplets and contacts are considered because of the main route of transmission. Epidemiological changes in COVID-19 infection should be monitored taking into consideration potential routes of transmission and subclinical infections, additionally to the variation, evolution, and virus spread among humans and possible intermediate animals and reservoirs. To identify the danger and prognostic factors of patients infected with SARS-CoV-2. As there's a priority for the spread of viruses thanks to cough induced by performing throat swabs, nasal swabs is also a comparatively safe and sensitive alternative to gather a respiratory specimen of patients with COVID-19. Rapid diagnostics play a very important role in disease and outbreak management. The fast and accurate diagnosis of a specific infection enables prompt and accurate public health surveillance, prevention, and control measures. ${ }^{(36)}$

Laboratory diagnosis could also be performed by (a) detecting the genetic material of the virus, (b) detecting the antibodies that neutralize the viral particles of interest, (c) detecting the viral epitopes of interest with antibodies (serological testing), or (d) culture and isolation of viable virus particles. ${ }^{(37)}$ Serological testing like ELISA, IIFT, and neutralization tests are eff ective in determining the extent of the infection, including estimating asymptomatic and attack rates. Compared to the detection of the viral genome through molecular methods, serological testing detects antibodies and antigens. Vaccines can prevent and protect against infection and disease occurrence when exposed to the specific pathogen of interest, especially in vulnerable populations who are at risk of severe outcomes. 
Table.1 Potential commercial rapid diagnostic kits for 2019-nCoV

\begin{tabular}{|c|c|c|c|c|c|}
\hline S.No & Type & Test & Sensitivity & Specificity & Reference \\
\hline 1. & RT-PCR & $\begin{array}{l}\text { RT-PCR Kit Master } \\
\text { Mix and q16 reaction } \\
\text { tubes included (for } \\
\text { gene sig® q16); PCR } \\
\text { Master Mix Kit (for } \\
\text { other instruments) }\end{array}$ & $\begin{array}{l}\text { Sensitive to < } \\
100 \text { copies of } \\
\text { target Broad } \\
\text { dynamic } \\
\text { detection range } \\
(>6 \text { logs })\end{array}$ & $\begin{array}{l}\text { Stated to be } \\
\text { high but with } \\
\text { no } \\
\text { accompanying } \\
\text { statistics }\end{array}$ & 10 \\
\hline 2. & RT-PCR & RT-PCR test kit & Not stated & Not stated & 11 \\
\hline 3. & RT-PCR & $\begin{array}{l}\text { Commercial Kit RT- } \\
\text { PCR kit }\end{array}$ & $\begin{array}{l}\text { Stated to be } \\
\text { high but with } \\
\text { no } \\
\text { accompanying } \\
\text { statistics. }\end{array}$ & $\begin{array}{lr}\text { Claims } & \text { with } \\
\text { lower } & \text { false } \\
\text { positive1 } & \end{array}$ & 12,13 \\
\hline 4. & RT-PCR & $\begin{array}{l}\text { Commercial Kit RT- } \\
\text { PCR kit }\end{array}$ & Not stated & Not stated & 14 \\
\hline 5. & RT-PCR & $\begin{array}{l}\text { Fluorescent RT-PCR } \\
\text { kit In vitro RT-PCR } \\
\text { combining } \\
\text { fluorescent probing } 1\end{array}$ & Not stated & Not stated & 15 \\
\hline 6. & $\begin{array}{l}\text { Combined } \\
\text { RT-PCR and } \\
\text { metagenomic } \\
\text { s detection }\end{array}$ & $\begin{array}{l}\text { 2019-nCoV PMseq } \\
\text { Kit A metagenomics } \\
\text { sequencing kit based } \\
\text { on combinatorial } \\
\text { Probe Anchor } \\
\text { Synthesis. Able to } \\
\text { detect both known } \\
\text { and novel } \\
\text { microorganisms, } \\
\text { Enabling monitoring } \\
\text { of evolution during } \\
\text { transmission }\end{array}$ & Not stated & Not stated & 16 \\
\hline 7. & Microfluidic & $\begin{array}{l}\text { enVision (enzyme- } \\
\text { assisted nano } \\
\text { complexes for visual } \\
\text { identification of } \\
\text { nucleic acids) Lab- } \\
\text { on-Chip platform } \\
\text { integrating PCR and } \\
\text { microarray }\end{array}$ & $\begin{array}{l}\text { Stated to be } \\
\text { high but with } \\
\text { no } \\
\text { accompanying } \\
\text { statistics. }\end{array}$ & $\begin{array}{l}\text { Stated to be } \\
\text { high but with } \\
\text { no } \\
\text { accompanying } \\
\text { statistics. }\end{array}$ & 17,18 \\
\hline
\end{tabular}


Table.2 Potential therapeutics

\begin{tabular}{|c|c|}
\hline Treatment & Stage \\
\hline Lopinavir-ritonavir & $\begin{array}{l}\text { Approved } \\
\text { Used in clinical settings. } \\
\text { The Jin Yintan Hospital in Wuhan, } \\
\text { China, launched a randomized, open- } \\
\text { label, blank-controlled trial for the } \\
\text { efficacy and safety of lopinavir-ritonavir } \\
\text { and interferon-alpha } 2 \mathrm{~b} \text { in the } \\
\text { hospitalization of } 80 \text { patients with novel } \\
\text { coronavirus infection. } \\
\text { Lopinavir-ritonavir tablets (each } \\
\text { containing } 200 \mathrm{mg} \text { of lopinavir and } 50 \\
\text { mg of ritonavir), twice a day, } 2 \text { tablets at } \\
\text { a time; interferon- } \alpha 2 \mathrm{~b} \text {. } \\
\text { Assessment of effectiveness of treatment } \\
\text { based on clinical improvement time of } 28 \\
\text { days after randomization. }{ }^{[21]}\end{array}$ \\
\hline Teicoplanin (Targocid) & $\begin{array}{l}\text { Approved. } \\
\text { Used in a clinical setting }\end{array}$ \\
\hline Remdesivir & $\begin{array}{l}\text { Gilead is in active discussions with } \\
\text { researchers and clinicians in the United } \\
\text { States and China regarding the ongoing } \\
\text { Wuhan coronavirus outbreak and the } \\
\text { potential use of remdesivir as an } \\
\text { investigational treatment. }{ }^{[22]}\end{array}$ \\
\hline Monoclonal antibodies & $\begin{array}{l}\text { Vir is working to rapidly determine } \\
\text { whether its previously identified anti- } \\
\text { coronavirus monoclonal antibodies } \\
\text { (mAbs) bind and neutralize 2019- } \\
\text { nCoV. }{ }^{[23]}\end{array}$ \\
\hline Monoclonal antibodies & $\begin{array}{l}\text { Regeneron Pharmaceuticals has } \\
\text { developed monoclonal antibodies to treat } \\
\text { MERS that are now being tested in early } \\
\text { human studies. A company spokesperson } \\
\text { said that researchers have begun to } \\
\text { identify similar antibodies that might } \\
\text { work against } 2019-n \text {-noV. With Ebola, it } \\
\text { took Regeneron six months to develop } \\
\text { candidate treatments and test them in } \\
\text { animal models. }{ }^{[24]}\end{array}$ \\
\hline Ritonavir + ASC09 combo & $\begin{array}{l}\text { Applied to include in a national } \\
\text { emergency channel on } 25 \text { January } 2020 . \\
\text { Not yet approved by regulators. }{ }^{[25]}\end{array}$ \\
\hline Galidesivir & Biocryst is evaluating Galidesivir to \\
\hline
\end{tabular}




\begin{tabular}{|c|c|}
\hline & $\begin{array}{l}\text { determine if it could potentially target the } \\
\text { coronavirus. Galidesivir is currently in } \\
\text { phase } 1 \text { clinical study. }{ }^{[6]}\end{array}$ \\
\hline $\begin{array}{l}\text { Molecules that inhibit } 2 \\
\text { coronavirus enzymes }\end{array}$ & $\begin{array}{l}\text { Molecules developed by the university } \\
\text { scientists inhibit two coronavirus } \\
\text { enzymes and prevent its replication. The } \\
\text { discovered drug targets are said to be } \\
\text { more than } 95 \% \text { similar to enzyme targets } \\
\text { found on the SARS virus. Researchers } \\
\text { note that identified drugs may not be } \\
\text { available to address the ongoing outbreak } \\
\text { but they hope to make it accessible for } \\
\text { future outbreaks. }\end{array}$ \\
\hline $\begin{array}{l}\text { "Xue bi jing” (TCM) - } \\
\text { ChiCTR2000029381 }\end{array}$ & $\begin{array}{l}\text { Approved. The recruitment of subjects } \\
\text { has not started. }{ }^{[28]}\end{array}$ \\
\hline $\begin{array}{l}\text { Adjunctive steroids have a } \\
\text { trial-ChiCTR2000029386 }\end{array}$ & $\begin{array}{l}\text { Approved. The recruitment of subjects } \\
\text { has not started. }\end{array}$ \\
\hline $\begin{array}{l}\text { Umefinovir } \\
\text { (arbidol)NCT04260594 }\end{array}$ & $\begin{array}{l}\text { Antiviral treatment for influenza } \\
\text { infection. The preliminary test in the in } \\
\text { vitro cell showed an effective inhibition } \\
\text { of coronavirus and a significant inhibition } \\
\text { of the cytopathic eff ect. }\end{array}$ \\
\hline Darunavir-NCT04252274 & $\begin{array}{l}\text { Antiviral treatment for HIV. The study } \\
\text { showed that it can significantly inhibit the } \\
\text { replication of the new coronavirus. }{ }^{[30]}\end{array}$ \\
\hline $\begin{array}{l}\text { Lopinavir Plus Ritonavir and } \\
\text { Arbidol }\end{array}$ & $\begin{array}{l}\text { Recruitment in the process; Interventional } \\
\text { subjects will receive either standard } \\
\text { treatment plus a regimen of lopinavir } \\
(200 \mathrm{mg} \text { ) and ritonavir ( } 50 \mathrm{mg} \text { ) (oral, } \\
\text { q12h, every time } 2 \text { tablets of each, taking } \\
\text { for } 7-14 \text { days) or Standard treatment plus } \\
\text { a regimen of arbidol ( } 100 \mathrm{mg} \text { ) (oral, tid, } \\
200 \mathrm{mg} \text { each time, taking for } 7-14 \\
\text { days). }\end{array}$ \\
\hline $\begin{array}{l}\text { Abidol hydrochloride, } \\
\text { Oseltamivir, } \\
\text { Lopinavir/ritonavir }\end{array}$ & $\begin{array}{l}\text { Recruitment of subjects has not started; } \\
\text { Interventional subjects will receive either } \\
\text { Abidol hydrochloride } 0.2 \mathrm{~g} \text { once, } 3 \text { times } \\
\text { a day, } 2 \text { weeks or Oseltamivir } 75 \mathrm{mg} \\
\text { once, twice a day, } 2 \text { weeks or } \\
\text { Lopinavir/ritonavir } 500 \mathrm{mg} \text { once, twice a } \\
\text { day, } 2 \text { weeks. }{ }^{[32]}\end{array}$ \\
\hline Hydroxychloroquine & $\begin{array}{l}\text { Recruitment in the process; Interventional } \\
\text { subjects will receive hydroxychloroquine } \\
400 \mathrm{mg} \text { per day for } 5 \text { days, also take } \\
\text { conventional treatments. }\end{array}$ \\
\hline
\end{tabular}


Vaccines against the 2019-nCoV are currently in development and none are interesting (at the time of writing). On 23 January 2020, the Coalition for Epidemic Preparedness Innovations (CEPI) announced that they'll fund vaccine development programs with Inovio, The University of Queensland, and Moderna, Inc respectively, to check the experimental vaccines clinically in 16 weeks (By June 2020).

The vaccine candidates are going to be developed by the DNA, recombinant, and mRNA vaccine platforms from these organizations. ${ }^{(37)}$ Lopinavir/ritonavir (Kaletra) was the earliest antiviral agent combination introduced for the treatment of SARS-CoV. Combined usage with ribavirin was also related to a lower incidence of acute respiratory distress syndrome, nosocomial infection, and death, amongst other favorable outcomes.

A known antimalarial agent, chloroquine, elicit antiviral effects against multiple viruses including HIV type 1, viral hepatitis, and HCoV-229E. Chloroquine is additionally immunomodulatory, capable of suppressing the assembly and release of things that mediate the inflammatory complications of viral diseases (tumor necrosis factor and interleukin 6). ${ }^{(38)}$ Thanks to the rapidly evolving situation of the 2019-nCoV, there'll be potential limitations to the systematic review.

Extensive measures should be taken to scale back person-to-person transmission of COVID-19 to regulate this outbreak. To scale back transmission special efforts and a focus should be applied to the population including children and elderly people. ${ }^{(13)}$ The most death causes of COVID-19 outbreak occurred mostly in elderly people thanks to their system which allows the faster progression of the infection. The overall public services and facilities should provide de-contaminating reagents for cleaning hands on a routine basis. Physical contact with wet and contaminated objects should be considered in handling the virus, especially agents like fecal and urine samples that will potentially function an alternate route of transmission. Recognition, quarantine, and treatment of the confirmed patients are critically important.

Over the past few years, the arena of corona virology has advanced significantly. The SARS epidemic and COVID-19 pandemic are a reminder that animal coronaviruses are potential threats to the human population. The outbreak of COVID-19 has become a clinical threat to the ultimate population and healthcare workers worldwide and up to now no promising clinical treatments or prevention strategies are developed against human coronaviruses. ${ }^{(34)}$

In kipping with certain studies, Corticosteroids didn't affect mortality, but they delayed the viral clearance. ${ }^{(40)}$ There's ongoing research for developing efficient therapeutic strategies to deal with the COVID-19.

Various broad-spectrum antivirals used against influenza, SARS, and MERS coronaviruses are evaluated either alone or in combinations to treat COVID-19 patients. Remdesivir, Lopinavir, and Ritonavir significantly blocked the COVID-19 infection in infected patients.

Also Chloroquine, medicine for the treatment of malaria showed remarkable inhibition within the spread of SARS-CoV and COVID19. The foremost effective because of cope up with this case is to chop back person-toperson transmission of COVID-19. ${ }^{(39)}$

In conclusion, it remains a challenging task to fight the 2019-nCoV of unknown origin and 
biological features and to manage an outbreak of COVID-19. Rapid diagnostics, vaccines, and therapeutics are key pharmaceutical interventions to limit the transmission of respiratory infectious diseases.

\section{References}

1. Arksey and O' Malley. Infectious Diseases of Poverty, 9, Jan 2020.

2. Fehr R.A and Perlman S. Coronaviruses: An Overview of Their Replication and Pathogenesis, 1282, New York 2015.

3. Cortegiani A, Ingoglia $\mathrm{G}$, Ippolito $\mathrm{M}$, Giarratano A, Einav S. A systemic review on the efficacy and safety of chloroquine for the treatment of COVID-19, March 2020.

4. Imperial College of London. Report 2: estimating the potential total number of novel coronavirus cases in Wuhan City, China. Jan 2020. https://www.imperial.ac.uk/mrcglobalinfectiousdisease-analysis/news-wuhan-coronavirus.

5. World Health Organization, 2019- nCoV Situation Report-22 on 12 February 2020. https://www.who.int/docs/defaultsource/cor onaviruse/situation-reports/

6. Luk HK, Li X, Fung J, Lau SK, Woo PC. Molecular epidemiology, evolution and phylogeny of SARS coronavirus. Infection, Genetics and Evolution 2019; 71: 21-30.

7. Coronavirinae in ViralZone. Available online: https://viralzone. expasy.org/785 (accessed on 05 February 2019).

8. Subissi L, Posthuma CC, Collet A, Zevenhoven-Dobbe JC, Gorbalenya AE, Decroly E, et al., One severe acute respiratory syndrome coronavirus protein complex integrates processive RNA polymerase and exonuclease activities. Proc Natl Acad Sci USA 2014; 111: E3900-E3909.

9. Charité Virology. Diagnostic detection of Wuhan coronavirus 2019 (17 January 2019). Available online: https://www.who.int/docs/default- source/coronaviruse/protocol-v21.pdf?sfvrsn=a9ef618c_2 (accessed on 28 January 2020).

10. Genesig. Novel coronavirus strain 2019ncov. Available online: https://www.genesig.com/products/10037n ovel-coronavirus-strain-2019-ncov. (accessed on 30 January 2020).

11. Today. Brief-jiangsu bioperfectus technologies develops test kit for new china coronavirus. Available online: https://www.todayonline.com/world/briefjiangsu-bioperfectus-technologiesdevelops-test-kit-newchina-coronavirus (accessed on 30 January 2020).

12. Co-Diagnostics Inc. Co-diagnostics inc designs test for new coronavirus using coprimer platform. Available online: http://codiagnostics.com/co-diagnosticsdesigns-new-coronavirus-test-usingcoprimers/ (accessed on 30 January 2020).

13. Genetic Engineering \& Biotechnology News. Coronavirus detection test in the works for wuhan. Available online: https://www.genengnews.com/news/corona virus-detection-test-in-the-works-forwuhan/ (accessed on 30 January 2020).

14. Altona Diagnostics. Altonadiagnostics is developing a rt-pcr it for detection of novel coronavirus(2019-ncov). Available online: https://altona-

diagnostics.com/en/news/assay-for-novelcoronavirus-under-development. html (accessed on 28 January 2020).

15. BGI. Bgi develops real-time fluorescent rtpcr kit for detecting the 2019 novel coronavirus. Available online: https://www.bgi.com/global/company/news /bgi-develops-real-time-dna-based-kit-fordetectingthe-2019-novel-coronavirus/ (accessed on 30 January 2020).

16. MGI. Bgi responds to novel coronavirus with real-time detection kits, deploys emergency team to wuhan. Available online: https://en.mgitech.cn/news/129/ (accessed on 30 January 2020).

17. $\mathrm{Ng}, \mathrm{R} . J$. Singapore biotech firm veredus expects to have wuhan virus test by feb 1 . Available 
https://www.businesstimes.com.sg/compan ies-markets/singapore-biotech-firmveredus-expectsto-have-wuhan-virus-testby-feb-1 (accessed on 30 January 2020).

18. Veredus Laboratories Pte Ltd. Veredus laboratories announces the development of a lab-on-chip for the detection of 3coronaviruses: Mers-cov, sars-cov and 2019-ncov. Available online: http://vereduslabs.com/ wordpress/wpcontent/uploads/2020/01/VereCoV-Press-

Release-Final.pdf (accessed on 30 January 2020).

19. BGI. Bgi develops real-time fluorescent rtpcr kit for detecting the 2019 novel coronavirus. Available online: https://www.bgi.com/global/company/news /bgi-develops-real-time-dna-based-kit-fordetectingthe-2019-novel-coronavirus/ (accessed on 30 January 2020).

20. Nct. Evaluate the safety, tolerability and immunogenicity study of gls-5300 in healthy volunteers. 2019. Available online: https://clinicaltrials.gov/ct2/show/study/NC T03721718? term $=$ vaccine $\&$ cond $=$ Mers $+C$ oV\& draw $=2 \&$ rank $=7$ (accessed on 28 January 2020).

21. Chinese Clinical Trial Registry. A randomized, open-label, blank-controlled trial for the efficacy and safety of lopinavirritonavir and interferon-alpha $2 b$ in hospitalization patients with novel coronavirus infection. Available online: http://www.chictr.org.cn/showprojen.aspx? proj $=48684$ (accessed on 29 January 2020).

22. Taylor, N.P. Gilead mulls repositioning failed ebola drug in china virus. Available online:

https:

//www.fiercebiotech.com/biotech/gileadmulls-repositioning-failed-ebola-drugchina-virus (accessed on 29 January 2020).

23. VIR. Vir biotechnology applying multiple platforms to address public health risk from wuhan coronavirus. Available online: https://investors.vir.bio/news-

releases/news-release-details/vir-

biotechnology-applyingmultiple-platformsaddress-public (accessed on 28 January 2020).
24. Science Mag. Can an anti-hiv combination or other existing drugs outwit the new coronavirus? Available online: https://www.sciencemag.org/news/2020/01 /can-anti-hiv-combination-or-otherexistingdrugs-outwit-new-coronavirus (accessed on 29 January 2020).

25. Today. Brief-ascletis pharma clarifies media reports on coronavirus treatment. Available online: https://www.todayonline.com/world/briefascletis-pharma-clarifies-media-reportscoronavirustreatment?cid=todayInsideToda ypage (accessed on 29 January 2020).

26. Speights, K. 5 biotech stocks to watch with the coronavirus scare. Available online: https://www.fool.com/ investing/2020/01/26/what-to-expect-inpfizers-q3-earnings-update.aspx (accessed on 29 January 2020).

27. Pharmaceutical Tech. Coronavirus: Gilead, purdue university explore potential treatments. Available online: https://www.pharmaceuticaltechnology.com/news/coronavirus-drugsdevelopment/ (Accessed on 29 January 2020).

28. Chinese Clinical Trial Registry. A prospective comparative study for xue-bijing injection in the treatment of pneumonia cause by novel coronavirus infection. Available online: http://www.chictr.org.cn/hvshowproject. aspx?id=21735 (accessed on 7 February 2020).

29. Chinese Clinical Trial Registry. Adjunctive corticosteroid therapy for patients with severe 2019-ncov pneumonia: A randomized controlled trial. Available online:

http://www.chictr.org.cn/showprojen.aspx? proj=48777 (accessed on 7 February 2020).

30. Mak, E. Coronavirus outbreak pushes Chinese biotech stocks higher despite market downturn. Available online: https://www.bioworld.com/articles/432890coronavirus-outbreak-pushes-chinesebiotech-stockshigher-despite-marketdownturn (accessed on 7 February 2020). 
31. ClinicalTrials.gov. The efficacy of lopinavir plus ritonavir and arbidol against novel coronavirus infection. Available online: https://clinicaltrials.gov/ct2/show/NCT042 52885 (accessed on 10 February 2020)

32. ClinicalTrials.gov. A prospective, randomized controlled clinical study of antiviral therapy in the 2019-ncov pneumonia. Available online: https://clinicaltrials.gov/ct2/show/NCT042 55017 (accessed on 10 February 2020).

33. ClinicalTrials.gov. Efficacy and safety of hydroxychloroquine for treatment of pneumonia caused by 2019-ncov (hcncov). Available online: https://clinicaltrials.gov/ct2/show/NCT042 61517 (accessed on 10 February 2020).

34. Lai C, Shih T, Ko W, Severe acute respiratory syndrome coronavirus 2 (SARS-CoV-2) and coronavirus disease2019 (COVID-19): The epidemic and the challenges, $\quad 2020$ https://doi.org/10.1016/j.ijantimicag.2020.1 05924

35. Lai C, Liu Yen H, Wang C, et al., Asymptomatic carrier state, acute respiratory disease, and pneumonia due to severe acute respiratory syndrome corona virus 2 (SARS-CoV-2): Facts and myths. 2020.https://doi.org/10.1016/j.jmii.2020.02
.012

36. Corman, V.M., Landt, O., Kaiser, M., Molenkamp, R., Meijer, A., Chu, D.K., Bleicker, T., Brünink, S., Schneider, J., Schmidt, M.L., et al., Detection of 2019 novel coronavirus (2019-ncov) by real-time rt-pcr. Eurosurveillance 2020, 25, 2000045. CEPI. Cepitofund three programmes to develop vaccines against the novel coronavirus, ncov-2019. Available online: https://cepi.net/news_cepi/cepi-to-fundthree-programmes-to-develop-vaccinesagainst-the-novelcoronavirus-ncov-2019/ (accessed on 29 January 2020).

37. Keyaerts,E.,Vijgen,L.,Maes,P.,Neyts,J.,Ran st,M.V.In vitro inhibition of severe acute respiratory syndrome coronavirus by chloroquine. Biochem. Biophys. Res. Commun. 2004, 323, 264-268. [CrossRef]

38. Rothan H, Byrareddy S, The epidemiology and pathogenesis of coronavirus disease (COVID-19) outbreak, 2020 https://doi.org/10.1016/j.jaut.2020.102433

39. Chaolin H, Yeming W, Xingwang L, et al., Clinical features of patients infected with 2019 novel coronavirus in Wuhan, China. Lancet 2020; 395: 497506.https://doi.org/10.1016/S01406736(20)30183-5.

\section{How to cite this article:}

Nikita Birhman, Mithilesh Kumar Singh, Shipra Tomar and Shrutika Pundir. 2020. Covid-19: A Silent Killer. Int.J.Curr.Microbiol.App.Sci. 9(05): 2710-2719. doi: https://doi.org/10.20546/ijcmas.2020.905.310 